\title{
MAKSUR DOME TRADITION IN THE DESIGN OF MALATYA GREAT MOSQUE IN TURKISH ISLAMIC ARCHITECTURE
}

| Received July $2^{\text {nd }} 2018$ | Accepted September $5^{\text {th }} 2018$ | Available online June $15^{\text {th }} 2019$

| DOI : http://dx. doi.org/10.18860/jia.v5i3.5204 |

\section{Alev Erarslan}

Istanbul Aydin University

Department of Architecture

Istanbul -Turkey

\begin{abstract}
The maksure section was added to Nebev-i Masjid during the era of the Caliph Osman in early Islamic architecture as a private space to ensure the safety and security of the caliphs. The maksure was positioned in the section in front of the mihrab and covered with a dome, eventually becoming one of the essential elements of Islamic mosque architecture. The "mihrab anterior dome" was at the same time regarded as a symbol of the ruler's sovereignty and became the fundamental starting point of spatial unity in mosque architecture. One of the most examples of this structure is the Umayyad Mosque in Damascus. The same plan layout was also applied to the mosques of Cordoba, Mesjid-i Aksa in Jerusalem, and Kayrevan in Tunisia. The anterior mihrab dome was an essential architectural and liturgical element used in the fabric of Anatolian mosque architecture by the Great Seljuqs outside Anatolia, the early-Anatolian Turkish Principalities, and Anatolian Seljuqs within the confines of Anatolia. After going through another stage of development during the late-Principality era of the $14^{\text {th }}$ century, it was transformed into the central dome in Ottoman Turkish architecture, becoming an essential element in the organization of the entire grammar of Turkish shrine architecture. This paper aims to describe the use of this mihrab anterior dome in the design of the Malatya Great Mosque. Evaluated within the scope of this typology, the Malatya Grand Mosque holds a unique place in the history of Turkish art and architecture, whether for its layout, its dome design, or its embellishment technique and repertoire. In this article, the Malatya Great Mosque, one of the "mihrab anterior dome" mosques in Anatolia, will be evaluated from the aspect of its unique dome plan and rich decorative embellishment program.
\end{abstract}

\section{KEYWORDS:}

Maksur dome, Malatya Great Mosque, Turkish Islamic architecture.

\section{INTRODUCTION}

The maksur dome is an essential architectural and liturgical element used in the texture of Anatolian mosque architecture outside of Anatolia by the Great Seljuq Turks as well as in Anatolia by the early Anatolian Turkish Principalities and Anatolian Seljuks [1]. Initially designed in early Islamic architecture as a private space to ensure the life safety of the caliphs, the maksure section of the mosque was added to the Nebevi Masjid during the era of Osman [2].

The Turks laid the foundations of their monumental Turkish architecture while entering Anatolia in the form of large and small Turcoman principalities in 1071 in the Battle of Manzikert [3]. Twelfth-century Anatolia marked the starting process of Turkish mosque architecture and the Turkish territories designed mosques with different types of layouts [4]. While a portion of these mosques was directly reproduced from Islamic architecture, another segment contained original experiments carried out by the early Anatolian Turkish Principalities based on the plan types that appeared under the influence of the Grand Seljuq Turks [5].

Widely used in the ancient Anatolian architecture, the "mihrab anterior dome" plan layout is comprised of subtypes with some variations. The mihrab anterior dome schematically emphasizes the section of the mosque situated in front of the mihrab in mosque architecture, thus bearing importance as a typology in and of itself [6]. In this type of plan, while the spatial arrangement develops around the mihrab anterior dome, the entire volume of the building is perceived as a whole when one wanders through the structure. The unique configuration of the mihrab axis in this section, also defined as the maksur, emerged from an allocation of this area as a private praying area for the caliph and his entourage [7]. Supported by different baldachin structures while underscoring a central accent, the mihrab anterior dome unit opens out onto side wings through arch openings. In this state, the element of the mihrab anterior dome paved the way for spatial systems with domes and pioneered the development of the central space in Islamic 
architecture [8].

The prototype providing a symbolic covering over this section and named the "mihrab anterior dome" was seen in the Damascus Umayyad Mosque (705-715) commissioned by the Umayyad Caliph, Velid I [9]. This is an original creation that breaks away from the earlyIslamic mosques of the hypostyle layout as a mosque plan constructed over the foundations of the Roman era Temple of Jupiter. By repeating the traditional multi-pillared layout (hypostyle), the mosque mihrab anterior comprised of three naves parallel to the qibla wall and revealed a new design with a section extending perpendicular to the qiblah wall and kept higher than the others. This section was also highlighted by being kept elevated in the outer mass. This cult structure features a high mihrab anterior dome, with a squinch supported by four columns that were designed as a wide transept perpendicular to the mihrab wall. Subsequent to the building of this mosque, others such as Mescid-i Aksa, Kayrevan, Cordoba, Tolunoğlu, and El Ezher repeated the mihrab anterior dome layout, which the volumetric integrity beneath the dome and the organic relationship with the side units in the qibla axis in the interior space were emphasized.

The first known example of the Turks' utilization of the imported element of the mihrab anterior dome came from the Ghaznavid Sultanate outside of Anatolia. The Leșkeri Bazar Grand Mosque stands adjacent to the protective walls of Leşkeri Bazar Palace and comprises two naves parallel to a mihrab with a transverse rectangular layout measuring $86 \times 10.50$ meters in the early $11^{\text {th }}$ century. As for the structure's mihrab anterior unit, the mihrab anterior dome stretches along the length of the two naves [10]. The dome is supported by six quadrangular brick pillars, four of which are free, the other two of which lean against the qibla wall and open out onto the side wings with arches.

Another example of the architectural form of the mihrab anterior dome from outside of Anatolia originates from the Karakhanids. Situated near Ancient Merv back to the late- $11^{\text {th }}$ to early $12^{\text {th }}$ centuries, the Talhatan Baba Mosque is an example notable for having no courtyard but a transverse rectangular-shaped sanctuary measuring $18 \times 10$ meters where there is a mihrab anterior dome that stretches out along the entire width of the structure's mihrab anterior (Figure 1). Supported by two wide pillars in the middle and by walls to the north and south, the squinched dome was enlarged with cross-vaulted volumes towards the sides so that spaces on the parties could be integrated into the main area. The dome offers the look of a central space dominating the entire sanctuary of the main space determined by the mihrab anterior dome.

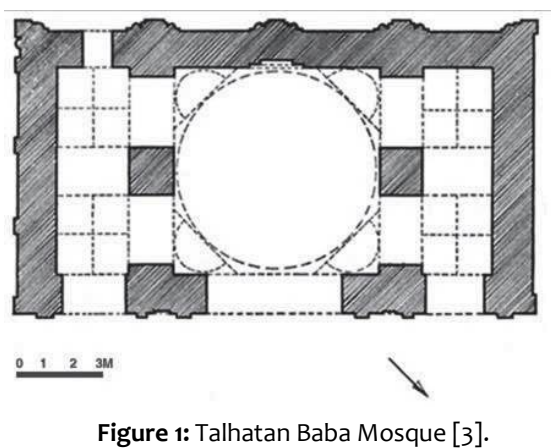

The most crucial stage of the evolution of the mihrab anterior dome outside of Anatolia emerges in the art of the Great Seljuqs. The Great Seljuqs created a new typology by adding a qibla iwan/mihrab anterior dome to the south iwan of a mosque constructed with an inner courtyard layout which having four iwans, as was used in the Arab mosques of Iran [11]. The first application of this new form was the Melikşah Dome of the Great Mosque of Isfahan (1080), where there is a notable example of the mihrab anterior dome (Figures $2,3)$. Here, the maksur dome, comprised of triplesegment brick squinches, is $\mathbf{1 5 . 2 0}$ meters in diameter and rests on bundle pillars connected with three arches on three sides so that the openings tie into the spaces on the parties [12]. Precisely opposite to the Meliksah dome and along the same axis is a second dome to the north of the courtyard that is known as Kümbet Haki and was built in honour of Melikşah's wife, Terken Hatun in 1088. This structure features almost the same layout principles. Staggered pointed arches were used from the floor to the dome in the triple-squinched domed space that is 10 meters in diameter. The Grand Seljuqs implemented this original invention of theirs in the Gülpayegan, Zevvare (1135) and Ardistan (1160), al-Cuma mosques in the region. It is thus ensuring the inclusion of the mihrab anterior dome in mosque schemes. According to the explanation in the introduction, the kind of dome seemed to be applied to many mosques in Turkey. So, this paper aims to find out whether the Malatya Great Mosque, as one of the best mosque in Turkey, use the mihrab anterior dome design or not. Meanwhile, this study also has an objective to describe and evaluate the dome design of the mosque.

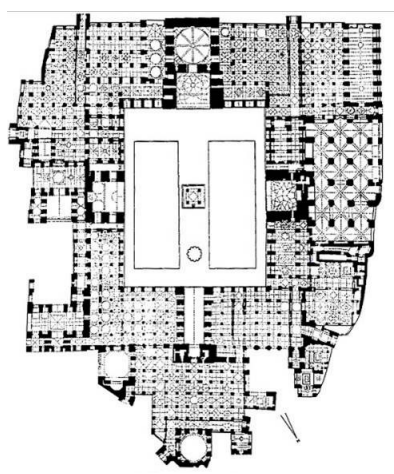

Figure 2: Plan of Isfahan Great Mosque 


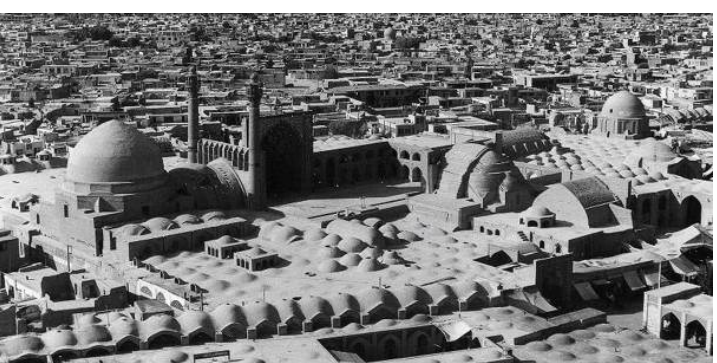

Figure 3: Isfahan Great Mosque

\section{METHODS}

This article assesses the Malatya Great Mosque, a unique amongst the Anatolian maksur domed mosques in terms of its plan, including the dome and iwan design, and evaluate its luxurious décor from the aspect of its layout and program of ornamentation. The author first introduces the maksur domed structures of Turkish religious architecture, then interprets the place of the Malataya Great Mosque, which occupies in this group of structures. The author travelled to the region, conducted an onsite investigation, and took photographs.

\section{RESULT AND DISCUSSION \\ THE MAKSUR DOME IN ANATOLIAN ARCHITECTURE}

The further development of the mihrab anterior dome subsequent to these examples evolved entirely in Anatolia. The first step of this development took place in the Bitlis and Siirt Great mosques. The buildings were designed without courtyards and were linked to the Great Seljuqs. After the implementation of the domeless mihrab anterior of the Damascus Umayyad Mosque model in the Diyarbakır Grand Mosque (1091), the mihrab anterior dome and iwan combination used by the Great Seljuqs in Iran was given a different interpretation. Here, the concept of adding a small dome over each of the two traverse rectangular vaulted naves and an iwan in front of the mihrab anterior dome has experimented [10] [12]. The transept of vaulted naves on the sides of the iwan is a notion that breaks away from the Grand Seljuq tradition [13]. Another early precursor of the mihrab anterior dome was the Bitlis Great Mosque (1150) with its dome covered on the exterior with a conical roof, and occupying only the width of one of its three vaulted naves running parallel to the qibla wall [14].

Great examples of the mihrab anterior dome in Anatolian Turkish architecture emerged in the architecture of the Artuqids. The assessment of the maksur dome under a different conceptual understanding in this period made it the center of gravity of the structure. In the Silvan (Meyyafarkin) Grand Mosque, which signifies the start of the splendiferous style of Artuqid architecture, the mihrab anterior dome is $\mathbf{1 3 . 5 0}$ meters in diameter and covers the width of three naves in the oblique, rectangular four-row space, thus dominating the entire sanctuary (Figure 4) [10]. The muqarnas squinched dome has three arched openings facing three directions and resembles the Melikşah dome in Isfahan [12]. Contrary to the structure itself, the dome is made of brick and is supported by ten pillars, two of which are embedded in the mihrab wall with the remaining eight standing free in the middle. The dome thus sits on an octagonal tambour and is covered on the exterior with a pyramidal cone [13]. Other representatives of this new style are the grand mosques of Mardin (1176) and KızIltepe (1204), where the mihrab anterior units are positioned along the length of two naves that are parallel to the mihrab in plan diagrams depicting a program of three naves opening out toward the width of the structure [15]. In all of the examples, the squinched mihrab anterior dome dominates the entire structure from the interior and exterior, while forming a balanced outer mass.

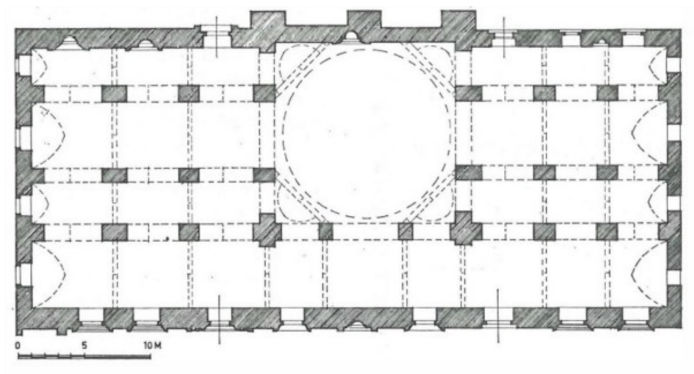

Figure 4: Silvan (Meyyafarkin) Grand Mosque's [12].

Another practice that may be assessed as part of the evolution of the maksur anterior dome in Anatolia is the increase in the number of traverse or perpendicular naves on each side of the structure and the fact that the maksur dome played a crucial role in determining the center of the structure's central axis. In this type, there is a luminous dome motif that provides a reference to the concept of the inner courtyard in the exact center of the structure on the same axis as the mihrab anterior dome in the central nave, which has been kept more comprehensive. Through the addition of a luminous dome to the mihrab anterior dome, the combination defines the main artery of the structure as well as a perception of the middle nave; the most beautiful examples in Anatolia of this structural feature are found in the Grand Mosques of Kayseri, Erzurum and Divriği as well as in the Kayseri Kölük Mosque (Figure 5) [16]. This application creates an effect of interior space where side spaces are integrated with the middle area. The structures are without courtyards, and the mihrab anterior dome defining the central nave dominates the entire structure both from the interior and the exterior.

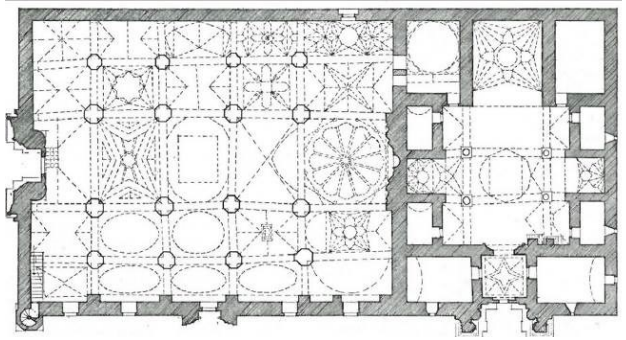

Figure 5: Divriği Great Mosque [12] 
Other versions of the utilization of the mihrab anterior in a multi-pillared hypostyle plan incorporating a dome in Anatolia can be seen in the Anatolian Seljuq era. conglomerate of stone and bricks. The structure features The first of these is Niğde Alaeddin Mosque, which was sanctuary and auxiliary sections separated from each commissioned by Alaeddin Keykubad in 1223 and featured other by a wall measuring $36.44 \times 57.22$ meters. The main a mihrab anterior dome unit that is incorporated in a element of the temple of the structure laid out by eight different structural setting. In this example, going beyond naves parallel to the mihrab in an overall nave widespread usage, three adjacent domes of various diam- arrangement is the mihrab anterior unit where the iwan eters have been positioned in front of a mihrab that is opens into the front inner courtyard to the north [18]. The comprised of three naves perpendicular to the mihrab. side enclosures surrounding this section - the naves - are Although this section gives the impression of forming a covered with vaults (Figure 8). The iwan in front of the traverse nave by breaking away from the structure mihrab anterior dome is a continuation of the inner through the use of ledged arches [13], it exhibits aside courtyard with the small pool in this mosque, which space arrangement integrated with the middle space. The includes the patio and iwan, and is situated along the three domes covering the sections of the naves in front of same middle axis (Figures 9, 10, 11).

mihrab wall were designed in different constructive features. While the mihrab anterior dome sits on muqarnas-filled squinches, the east dome rises over a pendentive squinch, and the west dome has eight segments sit on a muqarnas squinch. The domes bolster the imposing impact of the mass.

The different manner in which the Anatolian Seljuqs interpreted the mihrab anterior dome was based on the knowhow of the Great Seljuqs, but the Anatolian Seljuqs came up with a variation that embodied a local interpretation of the four-iwan courtyard layout. In this new tradition, the courtyard was transformed into a smaller, symbolic inner courtyard along the same axis-the central axis-as the mihrab anterior dome, while an attempt to revive the four-iwan scheme was made by the addition of a single iwan that opened into the courtyard only in front of the mihrab [17]. In this new Anatolian creation, the iwan is brought adjacent to the mihrab anterior dome in order to attain volumetric integrity with space.

The first example of this type of structure was the Konya Alaeddin Mosque. The mosque was commissioned by Alaeddin Keykubad in 1220 and comprised three sections. With different numbers of naves on the east and west, the structure stands on a flat-roofed multi-pillared hypostyle plan between two wings that constitute its main unit. This unit is a mihrab anterior dome section that manifests a Turkish-style triangular passage decorated with turquoise, navy blue and purple tiles (Fig X). In front of the mihrab anterior unit is a flat-roofed iwan. The mihrab anterior unit connects with the side spaces using large arches that support the maksur dome. The iwan in front of the mihrab opens directly into the courtyard.

\section{MALATYA GREAT MOSQUE}

As was seen in the example of the Konya Alaeddin Mosque, the use of the mihrab anterior dome is designed together with an iwan that opened into a courtyard in front. It was a type that was applied to a few examples amongst the Anatolian mosques of the early era. The most original example of this typology is a local Anatolian experiment that was implemented systematically and geometrically around a central inner courtyard, which can be seen in the Grand Mosque of Malatya, also known as Camii-Kebir (Figure 6, 7). Alaeddin Keykubad commissioned his master architect Yakup bin Ebubekir of Malatya to build this structure in 1224, and it was erected

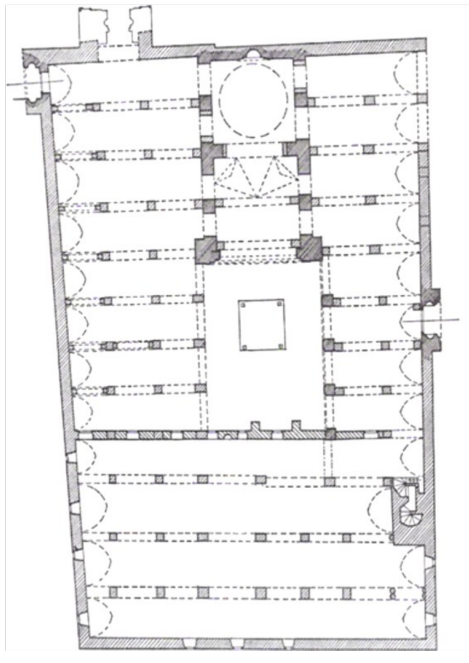

Figure 6: Plan of Malatya Great Mosque [10].

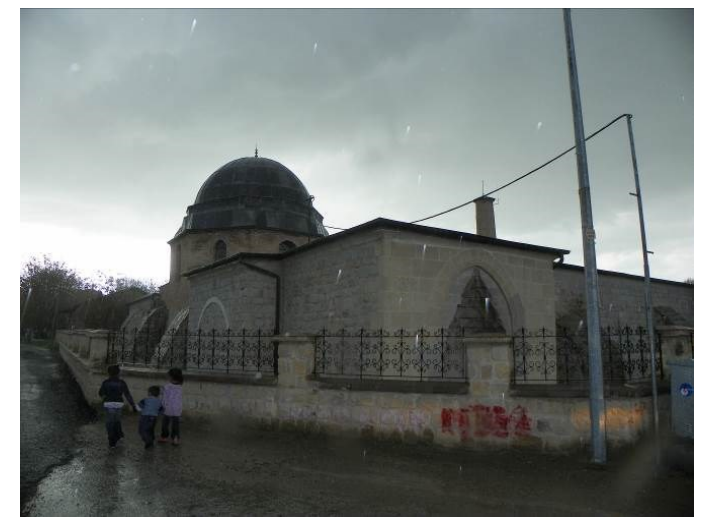

Figure 7: Malatya Great Mosque (Source: Author). 


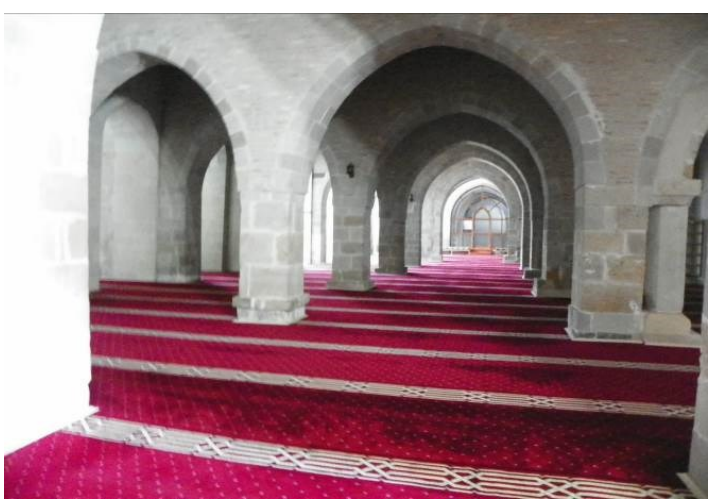

Figure 8: The naves of the mosque (Source: Author).

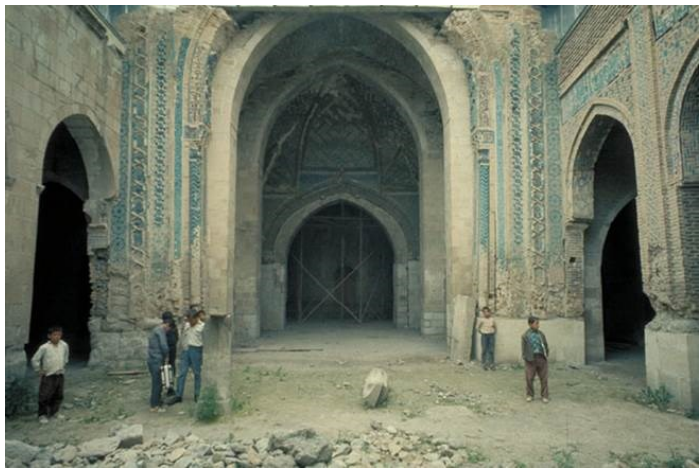

Figure 9: An old photo from the courtyard of the mosque. View of iwan. URL: https://archnet.org/media_contents/43069

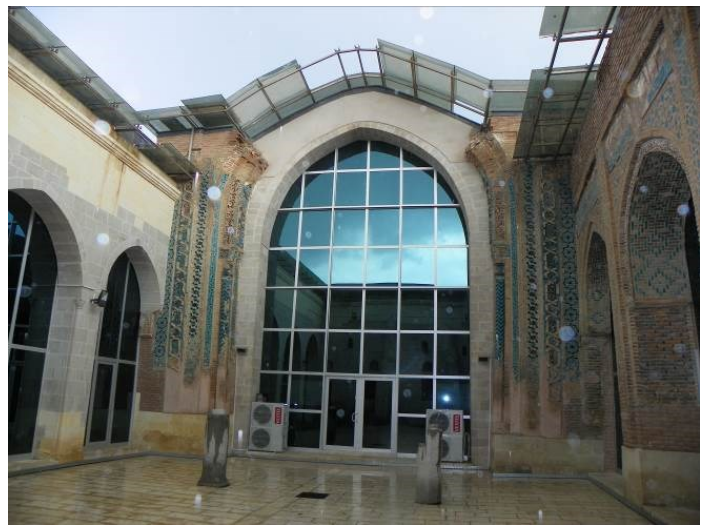

Figure 10: Current view of the court (Source: Author)

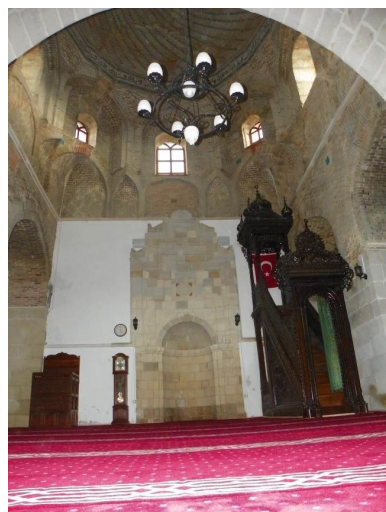

Figure 11: Mihrap of the mosque (Source: Author).
In the annexe to the north of the mosque, there is a separate mihrab with tandem domes along the length of the mihrab anterior that is situated anterior to the one in front. Functioning as a second mosque at the north of the structure, this section is separated from the actual mosque by a wall that was built to the north of the courtyard. Expanding the structure towards the south, the facade of this unit overlooking the yard is blind, but there are three windows here. There are two flying buttresses with pointed cones attached to this wall from the patio [19].

The brick of the mihrab anterior dome dominating the structure from the outside, and it is striking for the differentiating dome construction that takes it beyond a classic stance (Fig 12). The shape of the lower mass and upper covering exhibits a sophisticated style, and the dome covering a square area is supported by a system of six pillars, four of which are free-standing and the remaining ones leaning on the qibla wall. It opens out into the iwan in front and the side naves using pointed arches. Thus the dome features a six-pillared baldachin structure and sits on a two-staged octagonal tambour with threeleafed clover squinches, commonly used in Great Seljuq architecture. On the upper floor of the elevated tambour are windows that have been opened on the inside of the arches. From the standpoint of the interior space as well as of the shaping of the outer mass, the dome creates an impact of integration with the structure's main axis and manifests as a rather measured and balanced external mass.

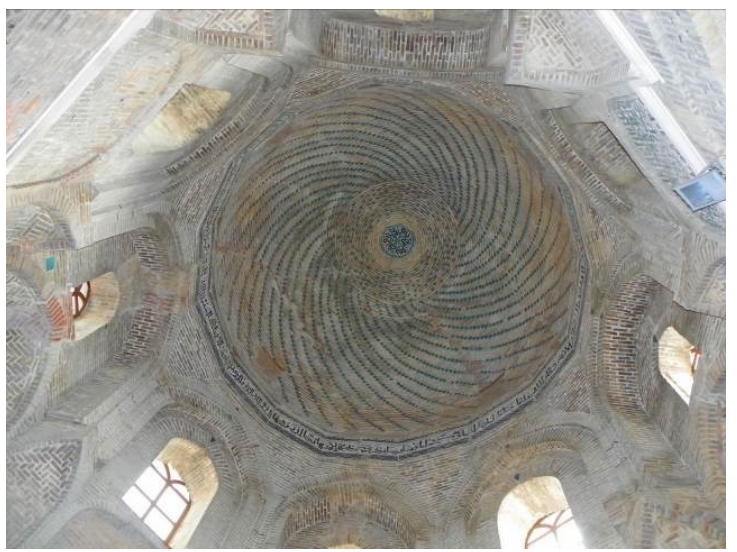

Figure 12: The maksur dome of the mosque (Source: Author).

Besides the dome, the structure is also among the distinctive examples of Turkish Art History for its decorative work. The building's glazed brick adornments with geometric and intertwining star decorations made from turquoise and eggplant purple porcelain mosaics along the edges of its dome, iwan and courtyard constitute a significant example of artwork and craftsmanship. While a spiral motif representing the circularity of the universe emerges from the diversely woven tiles interspersed among the basket-weave brick mortar inside the dome [20], at the exact center is a Süleyman's seal composition crafted from tiles of purple and ruby [21]. An inscribed frieze comprised of guilloche motifs is found on the drum of the 
dome. The dome's squinches are built from brick in zigzag cobalt blue. The colours used in the structure are range and diamond-shaped designs. The magnificent iwan vault from white, an occasional turquoise that turns into light in front of the mihrab anterior dome is decorated with a blue, cobalt blue, and purple. Of the two portals designed variety of motifs ranging from wide geometric shapes as masses overflowing from the structure's facade, the resembling kufi calligraphy, zigzags, diamonds and one on the west features geometric designs while the one herringbone, crafted from differently arranged stacks of on the east is ornated with stone masonry with floral bricks and triangular prisms [10]. The iwan vault is decorations [12]. The exterior of the structure is additionally completely encircled with a calligraphic intermittently supported by flying buttresses. inscription embellished with diamonds, curling branches and rumis. Tiled mosaics comprised of intertwining hexagons and ten-point stars are seen on the iwan arch (Figures 13, 14).

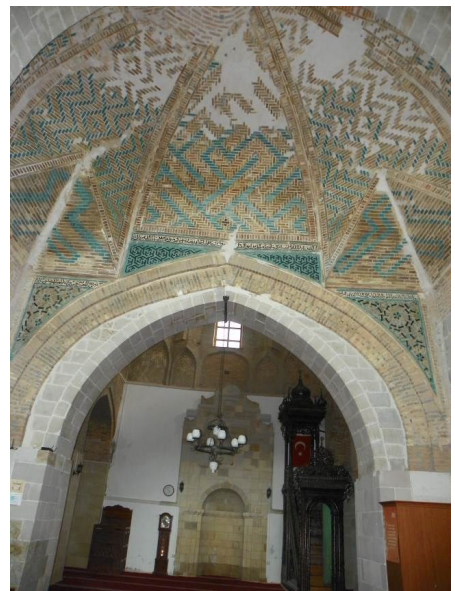

Figure 13: Iwan of the mosque (Source: Author).

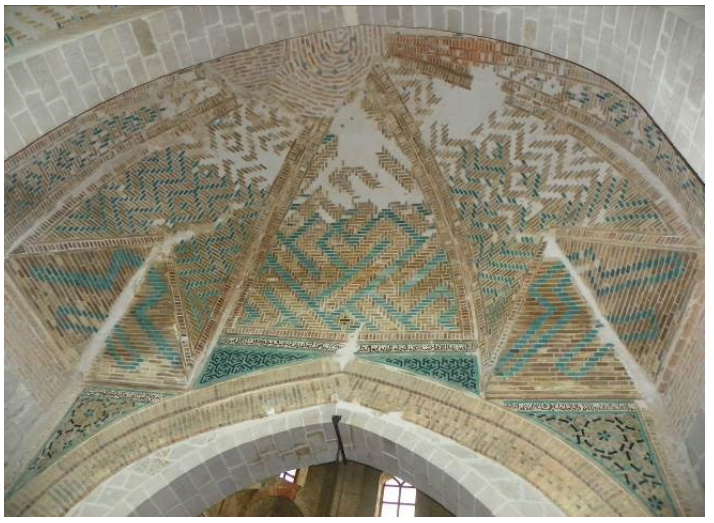

Figure 14: Iwan and tiles (Source: Author).

The structure's inner courtyard, featuring a pool, reflects some elegant examples of Turkish decorative art. It is situated in front of the iwan; the $10 \times 14$ meters courtyard are set out on a rectangular plan with patios on the east and west. It is embellished with colourful glazed brick tiles. The embossed rumis are striking here (Fig 15). The main motif of all of the structure's ledges and panels are embellished with geometric and linear arabesque decorations that consist of zigzag forms crafted with polygons on dark-coloured glazed brick or light-coloured mosaic tiles [16]. While the main decorative elements are bands of kufi and nesih style inscriptions, they are penned in two contrasting colours comprised of white, black or

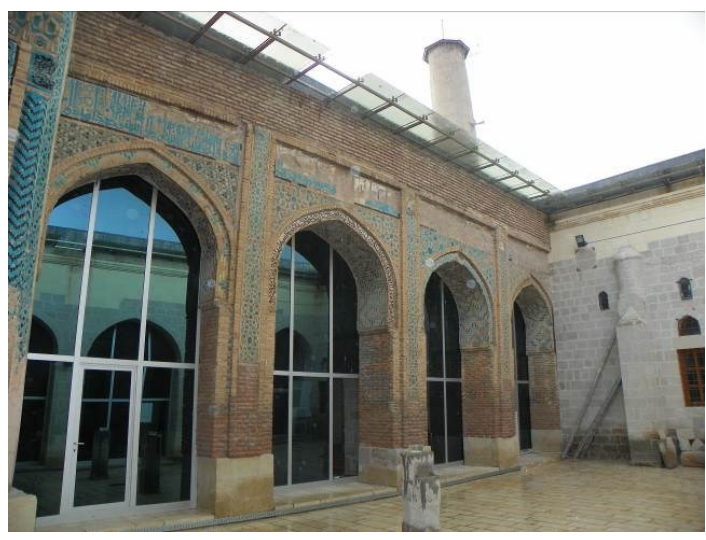

Figure 15: Arches in the courtyard (Source: Author).

\section{CONCLUSION}

As has been seen, the mihrab anterior dome was first used by the Umayyads in the Umayyad Mosque in Damascus. Its true development, however, evolved outside of Anatolia with the experimental endeavours and local additions of the Great Seljuq Turks, as well as of the early Anatolian Turkish Principalities and Anatolian Seljuqs. As an extremely crucial architectural and liturgic element that was incorporated into the texture of Anatolian mosque architecture. It was transformed into the central dome in Ottoman Turkish Architecture after its further progression during the Late-Principality era of the $14^{\text {th }}$ century when it became an important factor in the formation of the entire Turkish shrine architecture lexicon. Evaluated within the scope of this typology, the Malatya Great Mosque holds a unique place from the historical aspect of Turkish arts and architecture with respect to its plan, dome design, embellishment techniques as well as its repertoire. From the standpoint of the building's dome structure system, the structure represented a level of architectural style that stemmed from a new and local interpretation and synthesis of Great Seljuq and Anatolian architecture, while at the same time possessing a program of decorative arts that produced an extraordinary combination of cut stones, brick, glazed brick and tiles.

\section{REFERENCES}

[1] O. A. Basan, The Great Seljuqs, A History. London: Routledge, 2010.

[2] Y. ÇETIN, "ERKEN DÖNEM ISLAM CAMI MIMARISINDE MAKSURE KUBBESI GELENEČININ TÜRK CAMI MIMARIS," J. Acad. Soc. Sci. Stud., vol. 5, no. Number: 35, pp. 115-115, Jan. 2015. 
[3] G. A. Sargin, "Displaced Memories, or the Architecture of Forgetting and Remembrance," Environ. Plan. D Soc. Sp., vol. 22, no. 5, pp. 659-680, Oct. 2004.

[4] N. Avcioglu, "Identity-as-Form: The Mosque in the West," Cult. Anal., vol. 6, pp. 91-112, 2007.

[5] F. A. Mustafa and A. S. Hassan, "Mosque layout design: An analytical study of mosque layouts in the early Ottoman period," Front. Archit. Res., vol. 2, no. 4, pp. 445-456, Dec. 2013.

[6] M. Sözen and U. Tanyeli, Sanat Kavram ve Terimleri Sözlüğü. İstanbul: Remzi Kitabevi, 1996.

[7] A. Ödekan, "Emevi Mimarlığı ve Sanatı," Eczacıbaşı Sanat Ansiklopedisi. pp. 517-519, 1996.

[8] B. Batuman, "Architectural mimicry and the politics of mosque building: negotiating Islam and Nation in Turkey," J. Archit., vol. 21, no. 3, pp. 321-347, Apr. 2016.

[9] R. Alafandi and A. A. Rahim, "Umayyad Mosque in Aleppo Yesterday, Today, and," Int. J. Arts Sci., vol. 07, no. 05, pp. 319-347, 2014.

[10] O. Aslanapa, Türk Sanatı. Istanbul: Remzi Kitabevi, 1993.

[11] M. Cezar, Anadolu Öncesi Türklerde Şehir ve Mimarlık. Istanbul: Türkiye İş Bankası Kültür Publications, 1977.

[12] A. Altun, Ortaçağ Türk Mimarisinin Anahatları için Bir Özet. Istanbul: Arkeoloji ve Sanat
Publications, 1998.

[13] O. Aslanapa, Türk Sanatı II. Istanbul: National Education Printing House, 1972.

[14] N. Naz, "CONTRIBUTION OF TURKISH ARCHITECTS TO THE NATIONAL ARCHITECTURE OF PAKISTAN: VEDAT," METU JFA, vol. 22, no. 2, pp. 51-77, 2005.

[15] \& K. Agresi, Bayram, "Tourism at religious sites: a case from Mardin, Turkey," Geogr. Timisiensis, vol. 21, no. 1, pp. 5-15, 2012.

[16] S. Özaloglu and M. Ö. Gürel, "DESIGNING MOSQUES FOR SECULAR CONGREGATIONS: TRANSFORMATIONS OF THE MOSQUE AS A SOCIAL SPACE IN TURKEY," J. Archit. Plann. Res., vol. 28, no. 4, pp. 336-358, 2011.

[17] M. Güler and I. A. Kolay, "12. Yüzyıl Anadolu Türk Camileri," itü Dergisi/a, vol. 5, no. 2, pp. 83 $-90,2006$.

[18] O. Arık, "Malatya Ulu Camiinin Asli Planı ve Tarihi Hakkında," Vakıflar Magazine 8, pp. 141148, 1969.

[19] B. Eskici, "Eski Malatya Ulu Camii ve Cumhuriyet Dönemi Onarımları Üzerine," Konya Kitabı X, pp. 361-370, 2007.

[20] S. Ögel, Anadolunun Selçuklu Çehresi. Istanbul: Akbank Publications, 1994.

[21] A. Ödekan, "Anadolu Selçuklu Çağında Mukarnas Bezeme," in Selçuklu Çăğ'nda Anadolu Sanatı, D. Kuban, Ed. Istanbul: YKY, 2002, pp. 347-354. 